\title{
A survey of the potential for i-Build technology in improving the effectiveness of construction management in the Taiwanese construction industry
}

\section{Hung-Ju Chien*}

Minghsin University of Science and Technology,

1 Hsin-Sing Road, Hsin-Fong 30401

Hsinchu County, Taiwan

E-mail: lukechien@must.edu.tw

*Corresponding author

\section{Stephen Barthorpe}

MITIE Group PLC, 8 Monarch Court,

The Brooms, Emersons Green,

Bristol, BS16 7FH, UK

E-mail: stephen.barthorpe@mitie.co.uk

\begin{abstract}
Build technology is a state-of-the-art business integration tool, which includes all the functions of construction management for the enterprise and its partners. The aim of this paper is to examine the current awareness of i-Build and to identify its potential for improving the effectiveness of construction management in the Taiwanese construction industry. This paper reports on the findings obtained from a questionnaire survey conducted between November 2009 and January 2010, with contributions received from 50 organisations representing Taiwanese main contractors, construction companies, architects, engineering companies and clients. The results revealed that $5 \%$ of Taiwanese construction professionals have experience of using i-Build.
\end{abstract}

Keywords: information and communication technology; ICT; enterprise management; internet.

Reference to this paper should be made as follows: Chien, H-J. and Barthorpe, S. (2012) 'A survey of the potential for i-Build technology in improving the effectiveness of construction management in the Taiwanese construction industry', Int. J. Internet and Enterprise Management, Vol. 8, No. 1, pp.86-102.

Biographical notes: Hung-Ju Chien is an Assistant Professor at the Minghsin University of Science and Technology, Taiwan, one of his research areas is ICT application in construction management. Prior to joining Minghsin University in 2007, he was a Project Manager for Te-Chang Construction company for 13 years.

Stephen Barthorpe is the Sustainable Business Manager for MITIE, a major strategic outsourcing and asset management company. He is responsible for implementing sustainable business policies and practices. Prior to joining MITIE in 2005, he was a Principal Lecturer at the University of Glamorgan for 13 years, researching, publishing and teaching strategic management related 
topics including corporate social responsibility, corporate culture, ICT and environmental issues. He is a Chartered Builder, Chartered Building Engineer and Chartered Environmentalist.

\section{Introduction}

The implementation of information and communication technology (ICT) into the construction industry has been cited as one of the most important factors in the construction supply chain. New technology is providing a platform for improved communication within the supply chain and simultaneously integrates supply chain.

Currently, the ICT applications are classified under major headings including; internet, World Wide Web (WWW) and e-business (e-commerce), etc. These technologies are addressed in terms of their maturity in relation to the construction processes they are trying to support. Fundamentally, e-business (e-commerce) includes any form of electronic media, but it is increasingly associated with online transactions on the internet. Internet-enabled technologies provide a high degree of visualisation increasingly available to everyone. Furthermore, e-business (e-commerce) offers the construction industry a unique opportunity for economic growth by improving the whole industry's competitiveness and by stimulating investment in innovation and in creating new jobs.

This paper investigates the extent of the current use of i-Build by Taiwanese construction professionals. It also reports on the findings obtained from the questionnaire survey conducted by the authors between November 2008 and January 2009, with contributions received from 50 respondents representing Taiwanese main contractors, construction companies, architects, engineering companies and clients.

\section{Features and functional requirement of the i-Build}

i-Build can have four main constituent parts that are needed to run a successful construction business (see Figure 1).

- process management

- document management

- electronic commerce

- security.

\subsection{Opening viewing}

The opening view is a project directory or an individual project website depending upon how the service is provided (Graig, 2006). i-Build allows a single point of access for managing multiple documents and programmes. All information pertaining to the users' role will be delivered to their computer. It also indicates whether users have documents for review in their associated projects. For a single project, the access will be controlled 
at a project web page or beneath it. For example, the project website could have a public side on which general information about the project can be viewed by anyone (see Figure 2).

Figure 1 i-Build framework (see online version for colours)

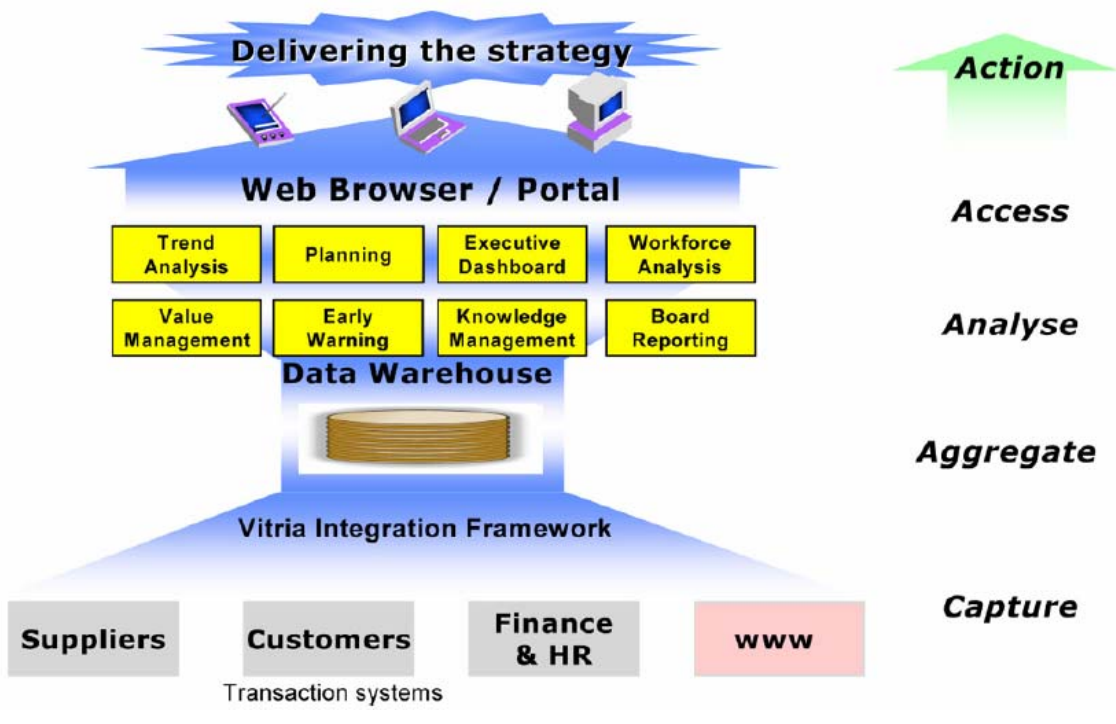

Source: Hogan (2001), adapted by the authors

Figure 2 Open view page (see online version for colours)

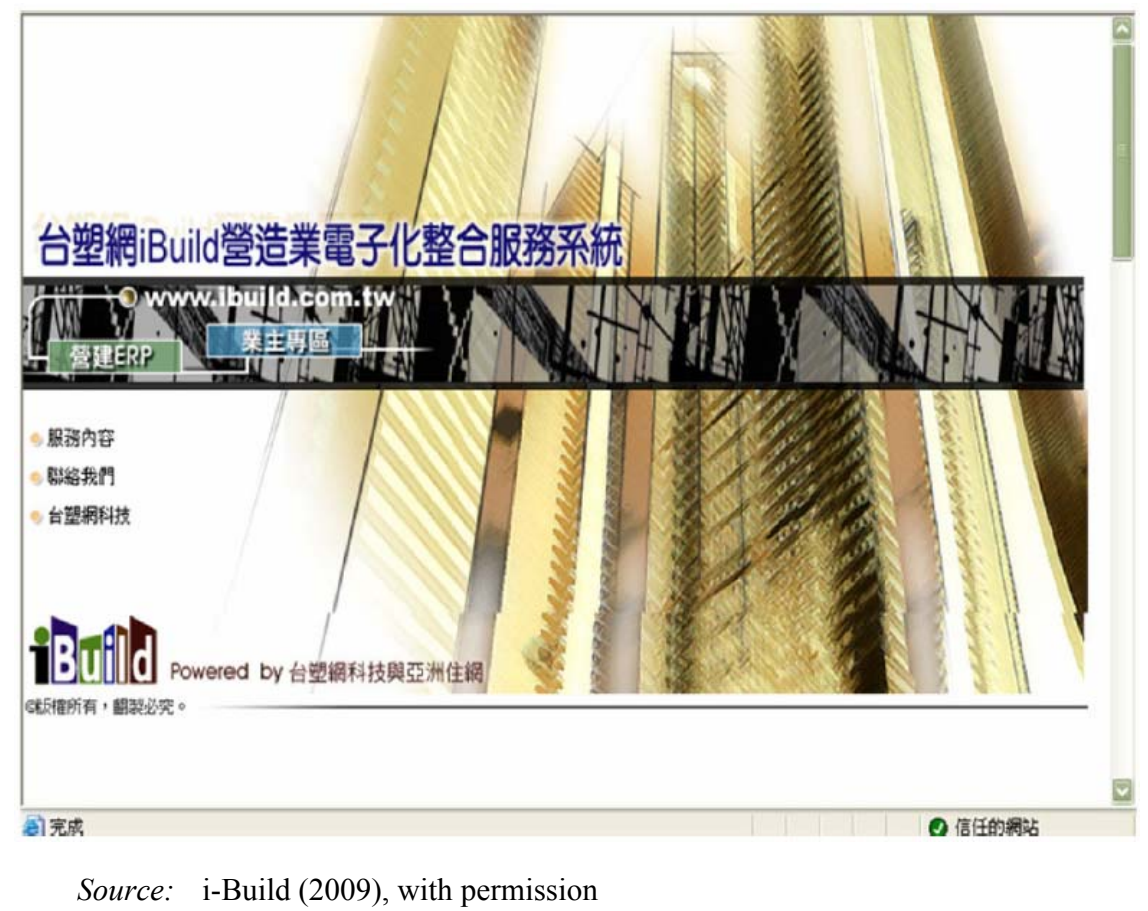




\subsection{Security}

The internet makes companies more vulnerable simply because it allows more entry points to their business. Using i-Build is also the case. ICT security is becoming an increasingly important issue since no system can be 100\% secure (Hamilton, 2002a). There can be a number of security levels to guard against unauthorised third-party access to sensitive information. For example, every user has a unique username and password (Figure 3). For added security, secure socket layering (SSL) can be added. All of the data is held on servers in physically secure premises, data is backed up regularly and servers monitored constantly for hackers, viruses and overall performance.

Figure 3 Log in page (see online version for colours)

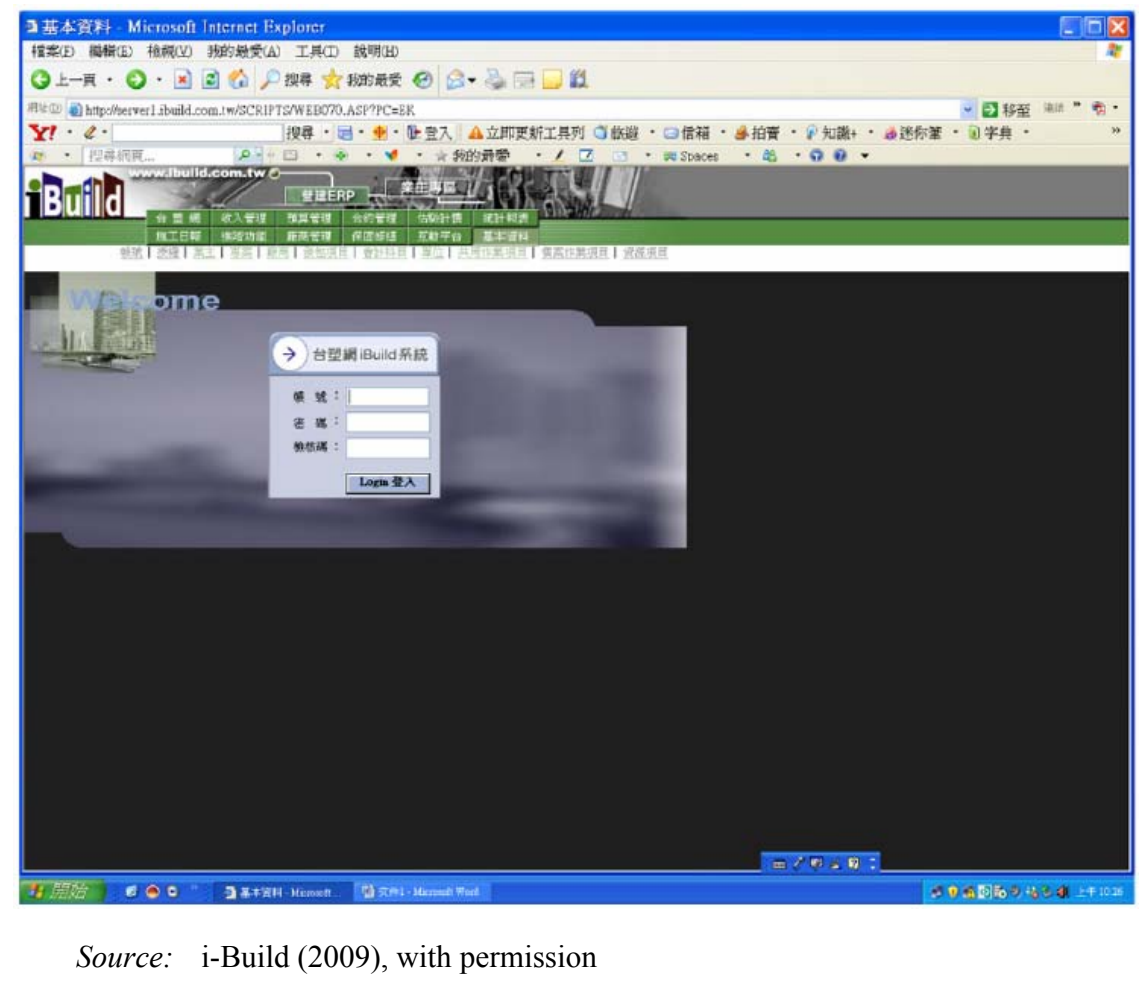

\subsection{Requests for information}

The requests for information (RFI) facility can be used to raise and answer questions, resolve issues of request information (BuildOnline Ltd, 2002). Individual users should need the appropriate permissions from the construction company to create an RFI. The construction company may also be able to configure routing rules for resolution, review, information and forwarding (Hamilton, 2002b; Figure 4).

The actual workflow routing used for RFI and submittals is likely to vary with the delivery model. For example, in the design-build model, there may be only isolated cases where it is necessary to route an RFI or a submittal through an owner (Graig, 2006). 
Figure 4 Requests for information (see online version for colours)

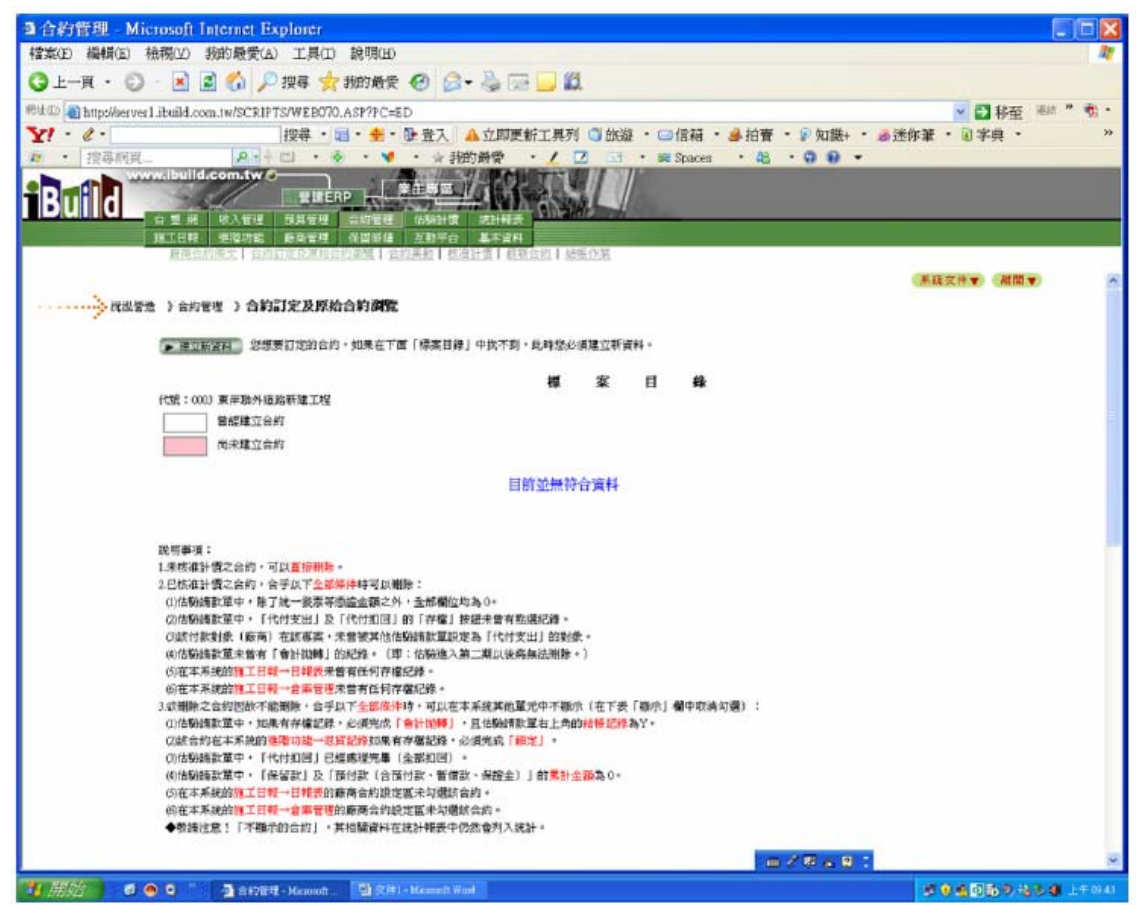

Source: i-Build (2009), with permission

Figure 5 Document management (see online version for colours)

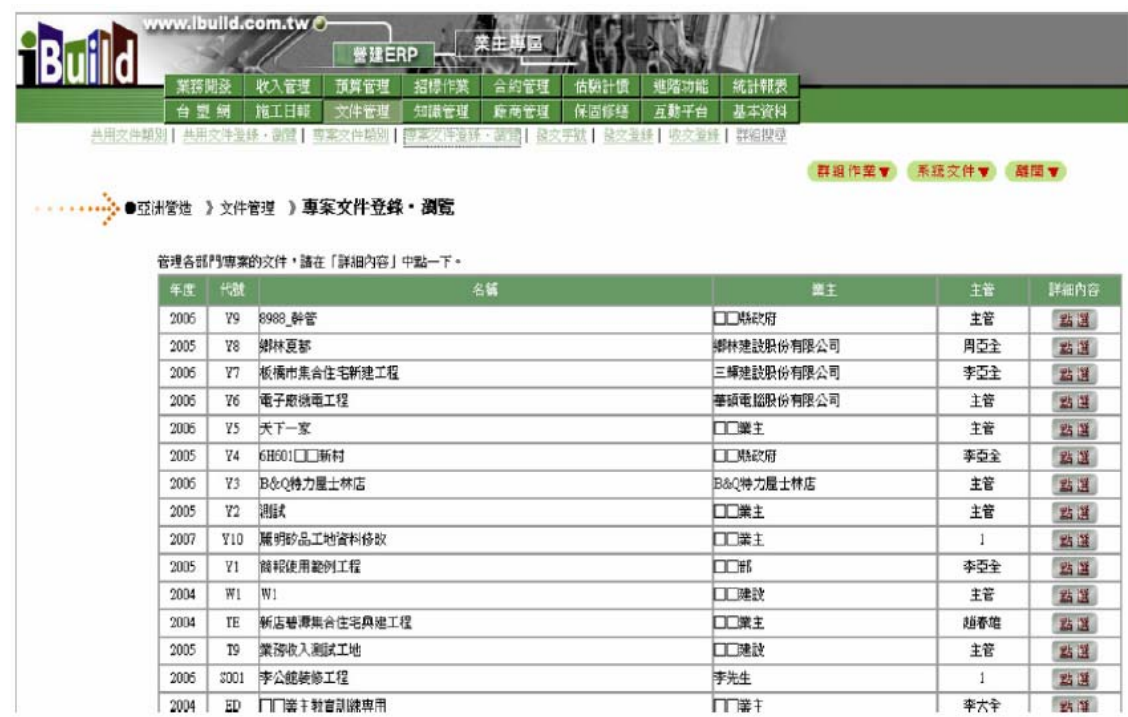

Source: i-Build (2009), with permission 


\subsection{Document management}

A significant amount of information is exchanged between various members in a construction supply chain. Poor communication and coordination, resulting in misunderstanding, misinterpretation and ignorance of information may seriously affect the performance of the project in terms of quality, time, cost and value (Cheng et al., 2001).

Document management provides all the features needed to allow the construction company to share and collaborate on project related documents as well as being able to route them to the right project participants for action and follow-up. Document management also allows the construction company to upload, download and revise documents as well as view and redline online. All activities are audited so that the enterprise is aware of all the history relating to a document (Figure 5).

\subsection{Contracts management}

The contract section manages multiple prime contracts, sub-contractor contracts and professional service agreements. The contract profile can be used to create the actual contract and display it within the i-Build system to authorised users. Change orders, purchase orders, back-charges, work orders and contract closeout documents can all be prepared and managed in the i-Build system (Graig, 2006). Furthermore, contractor invoices can be issued from the i-Build, just using a customised workflow process (Figure 6).

Figure 6 Contracts management (see online version for colours)

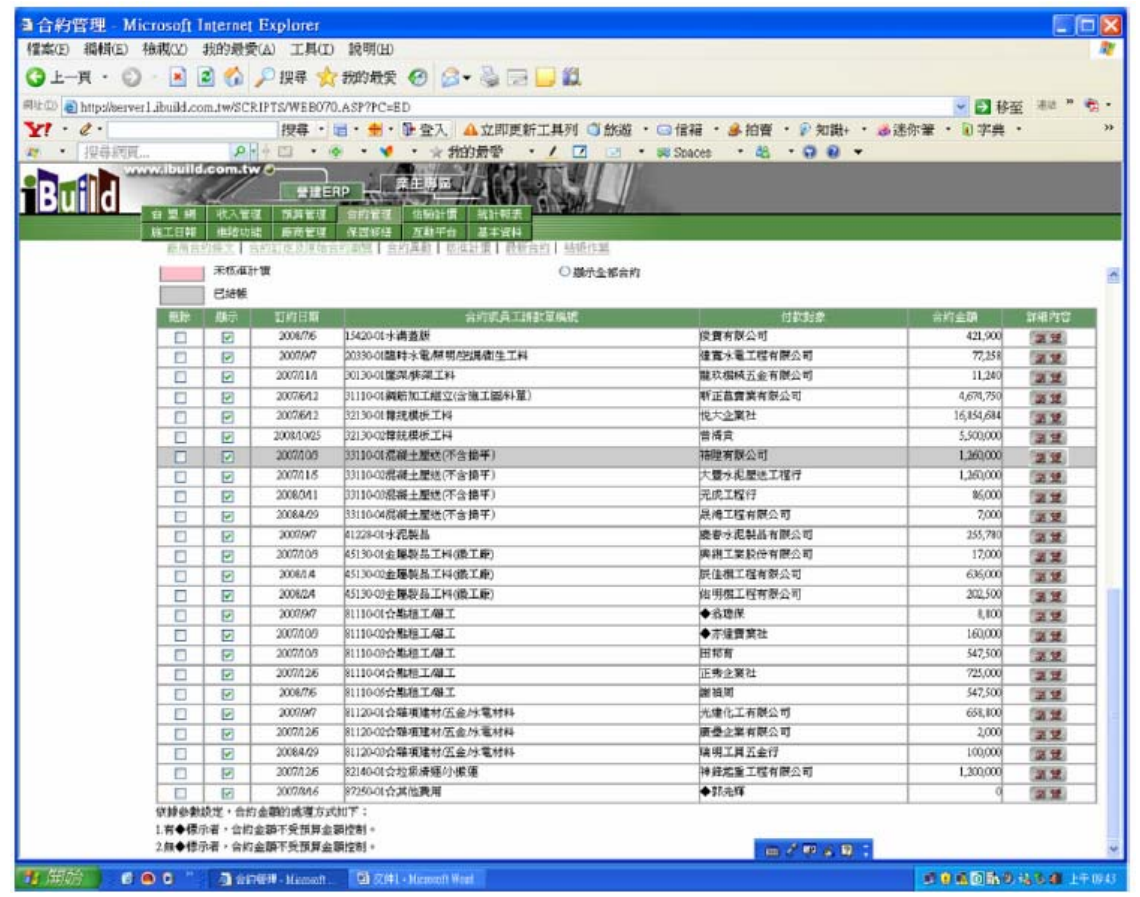

Source: i-Build (2009), with permission 


\subsection{Cost management}

Today, internet enabled customers have more information and more choice than ever. The one-size-fits-all days are gone, customers have high expectations and are increasingly demanding more tailored and customised services to suit their specific needs. Cost management provides all the features needed to allow the construction company to assess their cash flow. It also simultaneously issues the daily report of 'cash-in' and 'cash-out' of the project. Therefore, the enterprise could assess the cash flow of the project at any time (Figure 7).

Figure 7 Cost management (see online version for colours)

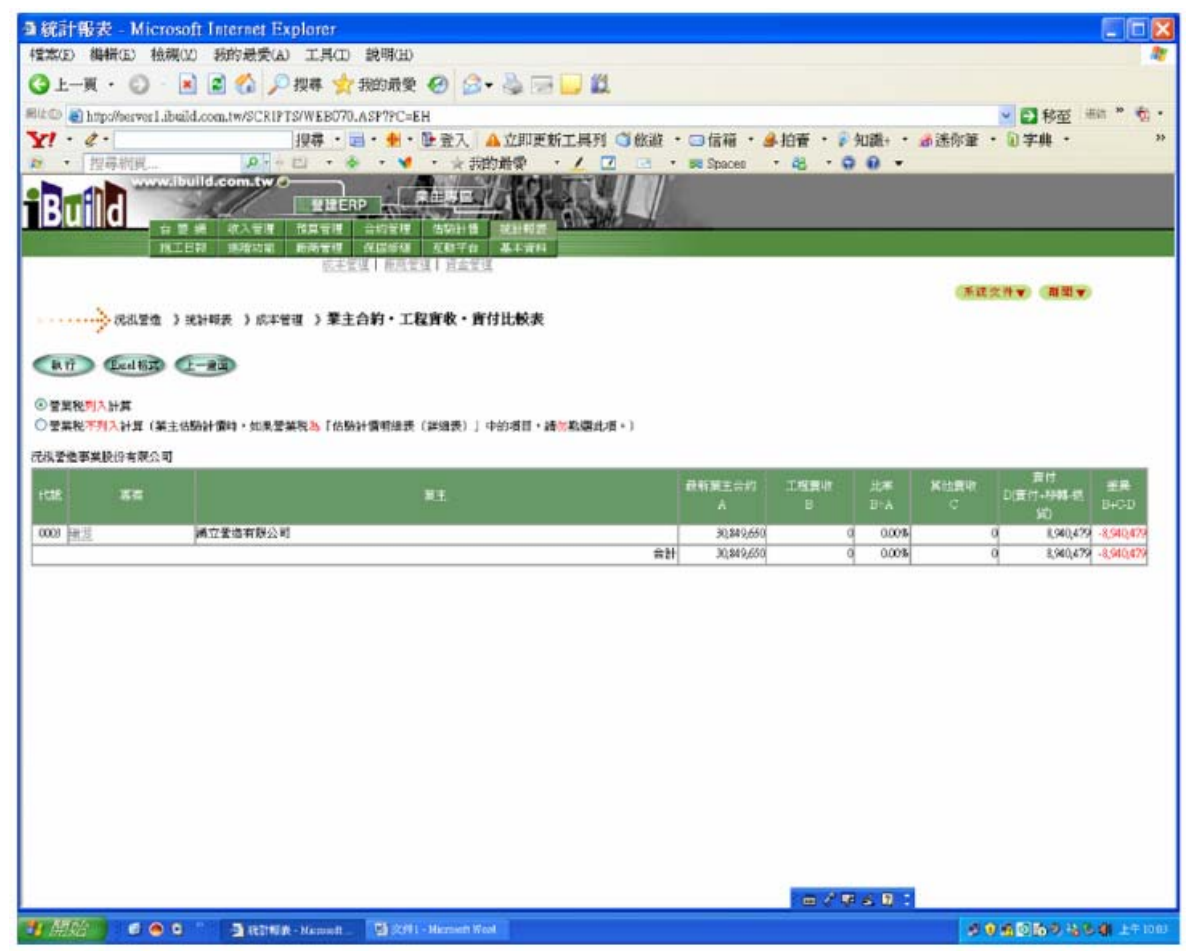

Source: i-Build (2009), with permission

\subsection{Management reports}

The management report within the i-Build system includes management reports and field reports. In general, the primary contract requires these features to keep the client and other members of the team apprised of the overall status of the project including schedule budget, significant issues, photographic progress and other items (Figure 8). 
Figure 8 Management reports (see online version for colours)

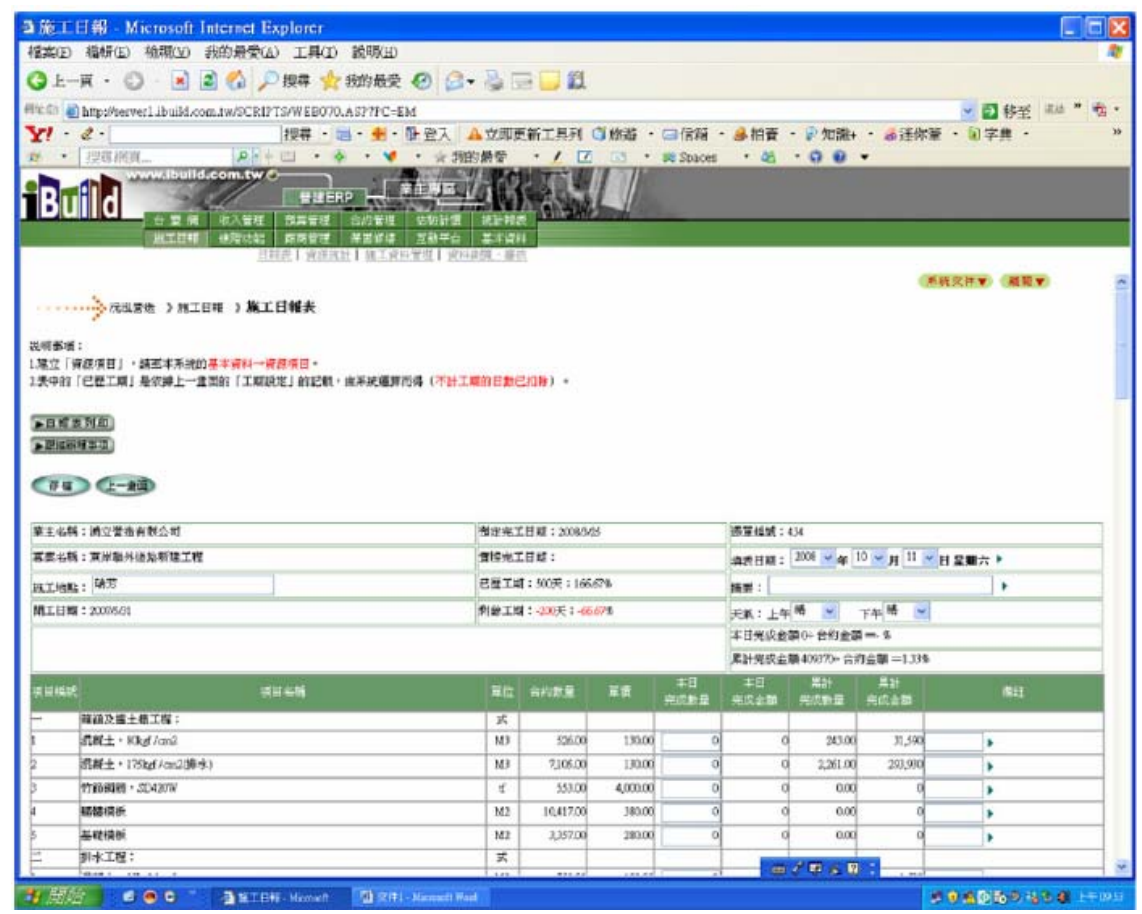

Source: i-Build (2009), with permission

\section{8 e-procurement}

In the traditional supply chain, buying and selling materials means establishing long-term relationships with suppliers, distributors and retailers, with multiple distribution centres, long lead-times and fixed margins. Now, all of the business activities are being re-innovated.

Companies can buy and sell across a wide internet-enabled marketplace - the virtual marketplace. Conditions such as challenging time-to-market, service response times and product lifecycles - are all factors that are key to market success. i-Build e-procurement solution offers another model for efficient internet purchasing. With e-procurement, enterprises can streamline entire purchasing operations from item selection through to approvals to payment and offers real-time interactivity with trading partners, dramatically reducing purchasing costs and boosting efficiencies to realise a rapid return on investment.

Furthermore, e-procurement also offers flexible functionality to cater for the different needs of first time, repeat and power users, allowing the user to select based on the user's business model. e-procurement was therefore designed to:

- provide new, industry leading search capabilities, which include text search, parametric search and categorisation and perform as people think (Figure 9) 
- e-procurement also provides a 'Smart Search' for supplier link-outs, so users can more easily find and link out to these external supplier sites

- e-procurement caters for frequent or experienced users, so they can complete their transactions quickly and handle checkouts in one step.

Figure 9 e-procurement (see online version for colours)

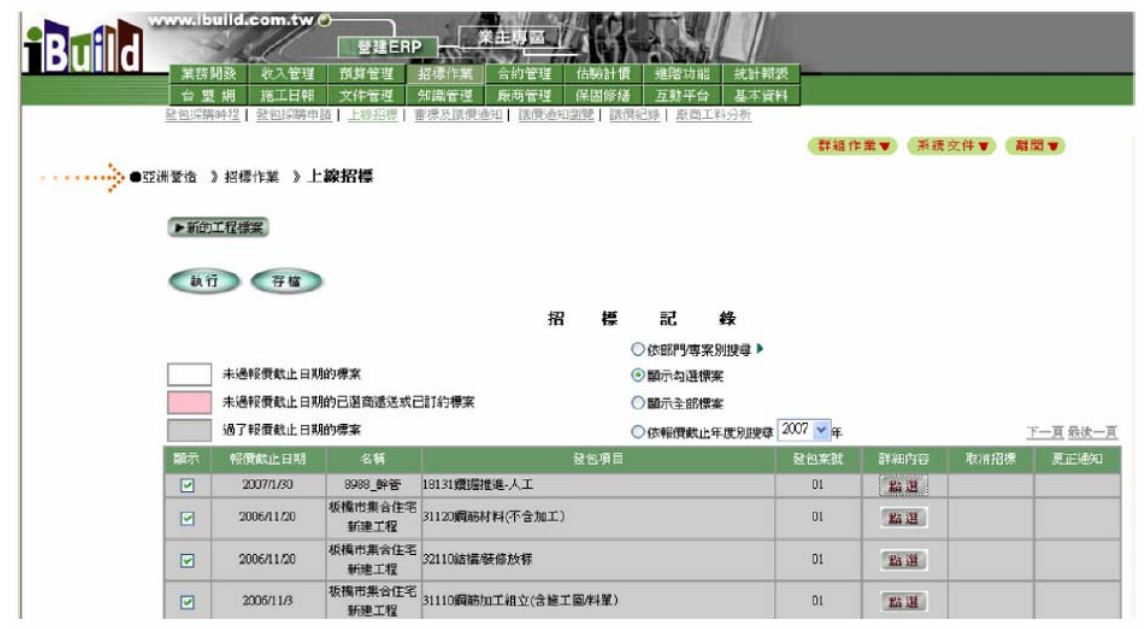

Source: i-Build (2009), with permission

\section{Research methodology}

To determine the current use of state-of-the-art i-Build technology by Taiwanese AEC companies, a questionnaire was conducted, which was designed and based upon a review of current literature and the research objectives. Two types of questions were used in the questionnaire; closed-ended questions and open-ended questions. Almost all the questionnaires have closed-ended questions to ensure consistency of respondent feedback. As it is not possible to design all questions as closed-ended, some questions were left open-ended, to obtain numerical data or to solicit some written comment. A total of ten multiple-choice questions were included in the questionnaire.

Before the main survey was undertaken, a draft version of the questionnaire was piloted with one Taiwanese construction company [turnover between Taiwan Dollar (TWD) 2-5 billion (USD 61-305 million)] and one Taiwanese engineering company [turnover between TWD 2-5 billion (USD 61-305 million)]. This pilot study was intended to elicit responses that would help to test the wording of the questionnaire, identify ambiguous questions and also provide an indication of the time to complete the questionnaire. Some of the comments and suggested amendments from the pilot study respondents were used to amend the questionnaire prior to its final distribution.

During November 2008 and January 2009, the authors conducted 50 telephone interviews with potential users of the i-Build technology. Interviewees were drawn from 50 different companies and comprised of main contractors, construction companies, 
architects, engineering companies and clients. Only 5\% of the interviewees had used i-Build technology on construction management.

The name and contact information of the interviewees were obtained from the authors' network of contacts and also from organisations such as the Taiwan Construction Research Institute (TCRI), Chinese National Association of General Contractors (CNAGC), Construction Magazine and Contractor Development Foundation (CDF). Some of the interviewee's names were obtained from the author's network of contacts, rather than from random selection. However although they can in no way be considered to representative of the industry as a whole they do provide important indications. Prior to making the telephone interview, a telephone call was made to each organisation in order to identify the person in the company with responsibility for ICT. In some organisations this person was known as the ICT manager but in most of the organisations, this person usually had other responsibilities apart from ICT. The data obtained from the authors' survey were analysed according to the type of profession, which was distinguished by five categories as indicated in Table 1.

Table 1 Categories of interviewees

\begin{tabular}{|c|c|c|c|c|c|c|}
\hline \multicolumn{7}{|c|}{ Annual turnover } \\
\hline Categories & $\begin{array}{c}\text { Below } \\
\text { TWD } \\
0.1 \text { billion }\end{array}$ & $\begin{array}{c}\text { Between } \\
\text { TWD } \\
0.1-1 \text { billion }\end{array}$ & $\begin{array}{c}\text { Between } \\
\text { TWD } \\
\text { 1-2 billion }\end{array}$ & $\begin{array}{c}\text { Between } \\
\text { TWD } \\
2-5 \text { billion }\end{array}$ & $\begin{array}{c}\text { Above } \\
\text { TWD } \\
5 \text { billion }\end{array}$ & $\begin{array}{l}\text { No. } \\
\text { interviewed }\end{array}$ \\
\hline Main & 8 & 11 & 7 & 2 & 0 & 28 \\
\hline Contractor & & & & & & \\
\hline Construction & 2 & 4 & 0 & 4 & 0 & 10 \\
\hline Company & & & & & & \\
\hline Architect & 1 & 0 & 0 & 0 & 0 & 1 \\
\hline Engineering & 5 & 2 & 0 & 1 & 0 & 8 \\
\hline Company & & & & & & \\
\hline Client & 1 & 0 & 0 & 1 & 1 & 3 \\
\hline SUM & 17 & 17 & 7 & 8 & 1 & 50 \\
\hline
\end{tabular}

\section{Data analysis using SPSS}

Statistical Package for the Social Sciences (SPSS) is a very powerful and user friendly programme for statistical analysis (Gaur and Gaur, 2006; Green and Salkind, 2008). The data obtained from the authors' survey was analysed in SPSS.

\subsection{Scale reliability}

Scale reliability is one of the SPSS techniques, has to be tested for validity and reliability. Proper validity and reliability testing can be done using confirmatory factor analysis (CFA). However, researchers commonly use the Cronbach alpha coefficient for establishing scale reliability. The Cronbach alpha coefficient is an indicator of internal consistency of the scale. A value of Cronbach alpha above 0.70 can be used as a 
reasonable test of scale reliability (Gaur and Gaur, 2006). The analysed results are shown in Table 2 where the Cronbach alpha value was calculated to be 0.914 (larger than 0.70 ).

Table 2 Reliability statistics

\begin{tabular}{lc}
\hline Crohbach's alpha & No. of items \\
\hline 0.914 & 8 \\
\hline
\end{tabular}

\subsection{The two-way ANOVA analysis}

An analysis of variance (ANOVA) exercise was undertaken to test the null hypothesis that there is no significant difference between the mean values of the groups. This enabled the authors to clarify whether or not the opinions of the separate construction professional groups were the same on the various issues dealt with in the survey.

A probability value of ' $F$ significant' (sig.) below 0.05 indicates that the null hypothesis can be rejected, suggesting that there is a high degree of difference of opinion between groups in relation to that factor. The ANOVA results are shown in Table 3 where the 'type of profession' has a significant effect on the 'reasonable monthly price' (sig. $=0.0030 .05)$. Furthermore, the interaction of the type of profession and annual turnover also does not affect the reasonable monthly price significantly (sig. $=0.579>$ $0.05)$.

Table 3 Tests of between subject effects

\begin{tabular}{lccccc}
\hline \multicolumn{7}{c}{ Dependent variable: reasonable monthly price } \\
\hline Source & Type III sum of squares & $d f$ & Mean square & $F$ & Sig. \\
\hline Corrected model & $19.702^{\mathrm{a}}$ & 12 & 1.642 & 2.232 & 0.035 \\
Intercept & 65.226 & 1 & 65.226 & 88.657 & 0.000 \\
Type of profession & 12.503 & 3 & 4.168 & 5.665 & 0.003 \\
Annual turnover & 6.228 & 4 & 1.557 & 2.116 & 0.102 \\
Type of profession* & 2.828 & 5 & 0.566 & 0.769 & 0.579 \\
Annual turnover & & & & & \\
Error & 23.543 & 32 & 0.736 & & \\
Total & 146.000 & 45 & & & \\
Corrected total & 43.244 & 44 & & & \\
\hline
\end{tabular}

Note: ${ }^{\mathrm{a}} \mathrm{R}$-squared $=0.456$ (adjusted R-squared $=0.251$ ).

A further analysis is therefore necessary to localise whatever differences there may be among the individual treatment means. Table 4 shows the differences between means [mean difference $(\mathrm{I}-\mathrm{J})$ ], their standard errors, p-values (sig.) and 95\% confidence interval for each pair. Inspection of the p-values shows that the 'engineering company group' differs significantly $(p>0.05)$. from the 'client group' in relation to the 'reasonable monthly price' factor, but the engineering company group does not differ significantly from the architect, the main contractor and the construction company groups $(\mathrm{p}>0.05)$. 
Table 4 Post hoc tests - multiple comparisons

\begin{tabular}{lcccccc}
\hline \multicolumn{5}{c}{ Dependent variable: reasonable monthly price } \\
\hline (I) group & $\begin{array}{c}\text { Mean } \\
\text { (J) group }\end{array}$ & $\begin{array}{c}\text { difference } \\
(I-J)\end{array}$ & Std. error & P-value sig. & $\begin{array}{l}\text { Lower } \\
\text { bound }\end{array}$ & $\begin{array}{c}\text { Upper } \\
\text { bound }\end{array}$ \\
\hline Client & $\begin{array}{c}\text { Engineering } \\
\text { company }\end{array}$ & -1.00 & 0.577 & 0.023 & -3.264 & -0.653 \\
\hline
\end{tabular}

\subsection{Chi-square test}

The chi-square test of independence is used to test the hypothesis that two categorical variables are independent of each other. A small chi-square statistic indicates that the null hypothesis is correct and that the two variables are independent of each other (Gaur and Gaur, 2006). Table 5 reveals that the Pearson chi-square (two-sided significance reported in the last column) is $0.008<0.05$, we can therefore reject the null hypothesis. In other words, there is significant relationship at $5 \%$ significance level between the professional group and annual turnover.

Table 5 Chi-square tests

\begin{tabular}{lccc}
\hline & Value & $d f$ & Asymp. sig. (two-sided) \\
\hline Pearson chi-square & $32.823^{\mathrm{a}}$ & 16 & 0.008 \\
Likelihood ratio & 25.372 & 16 & 0.064 \\
Linear by linear association & 0.049 & 1 & 0.825 \\
N of valid cases & 50 & & \\
\hline
\end{tabular}

Notes: ${ }^{2} 23$ cells $(92.0 \%)$ have expected count less than 5.

The minimum expected count is 0.02 .

\section{Survey results and discussion}

The results have been classified under the following headings:

- i-Build applications

- the appropriate level of cost and charging structures

- the noticeable benefits that have been gained from using the i-Build

- the barriers that discourage the construction industry from utilising the i-Build.

\section{1 i-Build applications}

There are many specialised i-Build applications that are designed specifically for use in construction. The respondents were invited to rate the level of usefulness in improving the effectiveness of construction management from the various i-Build applications. Mean ratings on the level of usefulness were calculated, (on a scale of 1-5) which revealed that project information management (3.90), cost management (3.84) and 
electronic document management (3.84) were considered to be the most useful in improving the effectiveness of construction management. The applications of programme management (3.82) and sub-contractor management (3.70) ranked fourth and fifth respectively (Table 6).

Table 6 i-Build application used by Taiwanese construction professionals

\begin{tabular}{lcccccc}
\hline i-Build applications & $\begin{array}{c}\text { Main } \\
\text { contractor }\end{array}$ & $\begin{array}{c}\text { Construction } \\
\text { company }\end{array}$ & Architect & $\begin{array}{c}\text { Engineering } \\
\text { company }\end{array}$ & Client & Average \\
\hline $\begin{array}{l}\text { Project information } \\
\text { management }\end{array}$ & 3.93 & 4.00 & 3.00 & 4.00 & 3.33 & 3.90 \\
$\begin{array}{l}\text { Cost management } \\
\begin{array}{l}\text { Programme } \\
\text { management }\end{array}\end{array}$ & 4.00 & 3.80 & 2.00 & 3.75 & 3.33 & 3.84 \\
$\begin{array}{l}\text { Knowledge } \\
\text { management }\end{array}$ & 3.89 & 3.90 & 3.00 & 3.63 & 3.67 & 3.82 \\
$\begin{array}{l}\text { Sub-contractor } \\
\text { management }\end{array}$ & 3.82 & 3.10 & 1.00 & 3.75 & 3.33 & 3.42 \\
$\begin{array}{l}\text { Electronic } \\
\text { document } \\
\text { management }\end{array}$ & 3.96 & 4.00 & 3.00 & 3.38 & 3.33 & 3.70 \\
$\begin{array}{l}\text { Customer } \\
\text { relationship } \\
\text { management }\end{array}$ & 3.32 & 3.10 & 1.00 & 3.50 & 3.00 & 3.24 \\
$\begin{array}{l}\text { e-procurement } \\
\begin{array}{l}\text { Financial } \\
\text { management }\end{array}\end{array}$ & 3.11 & 3.20 & 3.00 & 3.75 & 3.00 & 3.22 \\
\hline
\end{tabular}

Note: In a rating of 1 to 5 where 5 is most useful, 1 is least useful.

\subsection{Appropriate level of cost and charging structures}

The i-Build provider charges a flat monthly rate for the users. The price of such applications range is depending upon the level of functionality, the number of users and an estimation of the data storage required.

Figure 10 Reasonable monthly price of i-Build response analysis
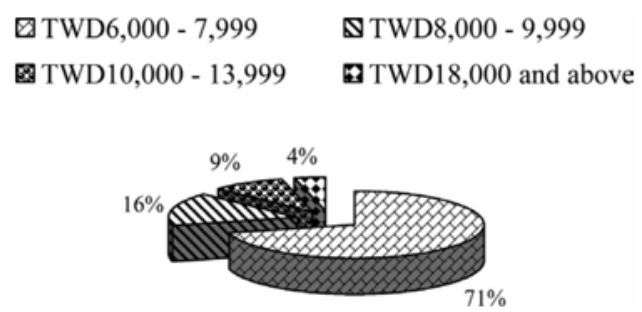

The authors' survey results revealed that the majority of respondents $(70.5 \%)$ indicated that a reasonable monthly price for 10 Giga bites $(\mathrm{Gb})$ data storage space and up to 100 system users is between TWD 6,000 and TWD 7,999. A further $15.9 \%$ reported that a reasonable level of monthly rate is between TWD 8,000 and TWD 9,999, only a small 
share of respondents $(9.1 \%)$ believed that an appropriate level of monthly price is between TWD 10,000 and TWD 13,999 (see Figure 10).

\subsection{The noticeable benefits that have been gained from using $i$-Build}

i-Build technology is now a state-of-the-art business collaboration tool in the Taiwanese AEC industry with $5 \%$ of Taiwanese construction professionals in the authors' survey indicating that they have experience of using the i-Build technology. Although $5 \%$ of responses seems a low figure at present, in reality, some respondents gained noticeable benefits from using i-Build. Some respondents commented that "In fact, with i-Build the return on investment is enormous", "Simple to implement in stages, meets our needs, we do not have to adapt our business processes to use them" and "i-Build is providing a platform for improved assessment within the value chain, and simultaneously issues the daily report of 'cash-in' and 'cash-out' of a project, it is easy for an enterprise to assess the cash flow of the project".

$65 \%$ of mistakes in the construction industry are due to a misunderstanding among architects, contractors and subcontractors over information, according to Bjornsson (2001). Oliver (2002) further commented, "The general statistic is that $80 \%$ of mistakes stem from not using the most up-to-date information".

The authors' survey has identified that one of the main advantages of using i-Build is that it ensures that all members of the project team have access to the most up-to-date versions of the various project documents. This means that traditional mistakes generated from someone working from an old document or drawing are in theory removed or at the very least reduced.

\subsection{The barriers that discourage the construction industry from utilising i-Build}

The barriers discouraging the effective implementation of i-Build in the Taiwanese AEC industry have been identified in the authors' survey. The results are illustrated in Table 7 and indicate that the three most significant barriers are:

- data may be altered in transit and delivery

- system reliability concerns

- appropriate charging structures.

The findings in the authors' survey are similar to those from the research conducted by $\mathrm{Ng}$ et al. (2001), White (2001), Goodwin (2001), Alshawi and Ingirige (2002), Oliver (2002), Sturley (2002) and Barthorpe and Chien (2003) who identified the reasons for the low level of ICT usage by construction professionals as:

- software problems

- confidential information getting into the wrong hands

- legal disputes arising.

However the order of importance of the various barriers has slightly changed. 
Table 7 Dependence levels of barriers - response analysis

\begin{tabular}{|c|c|c|c|c|c|c|}
\hline Factors & $\begin{array}{c}\text { Main } \\
\text { contractor }\end{array}$ & $\begin{array}{c}\text { Construction } \\
\text { company }\end{array}$ & Architect & $\begin{array}{l}\text { Engineering } \\
\text { company }\end{array}$ & Client & Average \\
\hline $\begin{array}{l}\text { Appropriate } \\
\text { charging structures }\end{array}$ & 3.94 & 4.00 & 2.00 & 2.83 & 3.00 & 3.61 \\
\hline $\begin{array}{l}\text { Confidential } \\
\text { information getting } \\
\text { into the wrong hands }\end{array}$ & 3.25 & 3.50 & 3.00 & 4.00 & 4.00 & 3.46 \\
\hline $\begin{array}{l}\text { Speed of information } \\
\text { transfer and delivery }\end{array}$ & 3.67 & 3.50 & 3.00 & 3.17 & 3.00 & 3.48 \\
\hline $\begin{array}{l}\text { System reliability } \\
\text { concerns }\end{array}$ & 3.80 & 4.25 & 2.00 & 3.17 & 3.00 & 3.63 \\
\hline $\begin{array}{l}\text { Data may be } \\
\text { altered in transit } \\
\text { and delivery }\end{array}$ & 4.00 & 3.25 & 2.00 & 3.83 & 4.00 & 3.78 \\
\hline $\begin{array}{l}\text { Legal disputes } \\
\text { arising }\end{array}$ & 3.07 & 3.50 & 2.00 & 3.50 & 4.00 & 3.23 \\
\hline
\end{tabular}

Note: In a rating of 1 to 5 where 5 is most important, 1 is least important.

\section{Limitation of the survey}

According to Samuelson (2008), 'IT - Barometer 2007 survey' stated that "Three criteria were set up for the survey tool". It should:

- be repeatable and comparable over time

- be comparable between countries

- cover all categories in the construction industry.

Although the purpose of this survey is to examine the current state of i-Build technology usage by Taiwanese AEC companies, there are several limitations and constraints that have influenced the response obtained in this survey:

- Unfamiliarity of i-Build applications: i-Build is a relatively new technology, particularly by Taiwanese AEC companies and therefore some interviewees were unfamiliar with the i-Build applications available or even the esoteric terminology used.

- Constraints of conducting structured interviews: Although a substantial empirical study was conducted using the questionnaire survey, the expense and time-consuming nature of conducting structured interviews limited the number that 
were able to be carried out. However although 50 structured interviews can in no way be considered to be representative of the industry as a whole they do provide important indications.

- Analysis constraints: Some difficulty was experienced in analysing some of the survey interviewee's comments, due to their subjectivity.

\section{Conclusions}

This paper has presented the findings of a questionnaire survey conducted by the authors among a sample of 50 construction organisations based in Taiwan. The survey results demonstrate that only $5 \%$ of the survey respondents have experience of using i-Build. The three most significant barriers that discourage the AEC industry from utilising the iBuild have also been identified in this paper as:

- data may be altered in transit and delivery

- $\quad$ system reliability concerns

- $\quad$ appropriate charging structures.

From the survey, the majority of respondents (70.5\%) indicated that a reasonable monthly price for $10 \mathrm{~Gb}$ data storage space and up to 100 system users is between TWD 6,000 and TWD 7,999. Furthermore, the respondents indicated that the three i-Build applications that were the most useful in improving the effectiveness of construction management in the Taiwanese AEC industry are:

- $\quad$ project information management

- cost management

- $\quad$ electronic document management.

The Taiwanese construction industry output is annually worth around TWD 469 billions, roughly equivalent to $5 \%$ to $6 \%$ of the gross domestic product (MOI, 2004). According to the MOI report, there were 12,012 construction companies in 2008 . Only 5\% of these organisations have so far implemented i-Build system, therefore a $95 \%$ potential construction market for i-Build system exists in this sector alone.

The ICT technology infrastructure is now available for construction in enhancing business performance and future growth. i-Build applications are just one of several possible solutions that can be used to streamline construction processes, form closer client/subcontractor/supplier relationships and operate more effectively in the global market place.

\section{Acknowledgements}

The authors would like to acknowledge the contribution of the construction professionals who participated in this survey. 


\section{References}

Alshawi, M. and Ingirige, B. (2002) 'Web-enabled project management', Centre for Construction Innovation (CCI) report, Manchester UK, available at http://www.ccinw.com.

Barthorpe, S. and Chien, H.J. (2003) 'The current state of ICT usage by UK construction companies', International Journal of Electronic Business, Vol. 1, No. 4, pp.1-15.

Bjornsson, H. (2001) cited in Hogan, P. (2001) 'E-construction', p.13, MSc dissertation unpublished, University of Salford, Manchester UK.

BuildOnline Ltd (2002) 'Project online features', Company Brochure, available at http://www. BuildOnline.com.

Cheng, E.W.L., Li, H., Love, P.E.D. and Irani, Z. (2001) 'An e-business model to support-supply chain activities in construction', Logistics Information Management, Vol. 14, Nos. 1-2, ISSN 0957-6053, pp.68-77, MCB University Press.

Coopers and Lybrand (2001) cited in Hogan, P. (2001) 'E-construction', p.13, MSc dissertation unpublished, University of Salford, Manchester UK.

Gaur, A.S. and Gaur, S.S. (2006) Statistical Methods for Practice and Research - A Guide to Data Analysis using SPSS, ISBN 0-7619-3502-9, Sage Publication Ltd., London, UK.

Goodwin, P. (2001) 'Effective integration of IT in construction', A partners in innovation project final report, The Building Centre Trust, London, UK.

Graig, W.G (2006) 'The use of a project extranet for any project delivery method', ProjectEDGE.com, New York, USA.

Green, S.B. and Salkind, N.J. (2008) Using SPSS for Windows and Macintosh: Analysing and Understanding Data, ISBN-13: 978-0-13-189025-1, Pearson Education Ltd., London, UK.

Hamilton, I. (2002a) 'The big issues in construction it construction news it report', Report No. 5346, published on March 26, Econstruction Yearbook, available at http://www.cnplus. co.uk/IT/ReportDetails/?channelid=10\&report ID=5346.

Hamilton, I. (2002b) 'Management online', Construction Manager, December 2001 to January 2002, p.41, CIOB Journals Ltd., London, UK.

Hogan, P. (2001) 'E-construction', MSc dissertation unpublished, University of Salford, Manchester, UK.

Howarth, G.J. (2002) 'The living building', Construction News, published on April 15, available at http://www.cnplus.co.uk/proj_collaboration/?pid=3\&sid=84\&aid=22878.

Ng, S.T., Chen, S.E., McGeorge, D., Lam, K.C. and Evans, S. (2001) 'Current state of IT usage by Australian subcontractors', Construction Innovation, Vol. 1, No. 1, pp.3-13, Arnold, Hertfordshire, UK.

Oliver, M. (2002) cited in Lane, T. (2002) 'A man and his tools', Building Magazine, published on November 15 , available at http://www.building.co.uk/story.asp? storyType=25\&sectioncode= $33 \&$ storyCode $=1023334$.

Samuelson, O. (2008) 'The IT-barometer - a decade's development of IT use in the Swedish construction sector', Electronic Journal of Information Technology in Construction, Vol. 13, pp.1-19.

Sturley, R. (2002) Project extranets, now and the future', Presentation at the Cadweb Conference 2002, 22 May 2002, London UK, available at http://www.cadweb.co.uk.

Veeramani, D., Tserng, H.P. and Russell, J.S. (1998) 'Computer-integrated collaborative design and operation in the construction industry', Automation in Construction, pp.485-492, Elsevier Science B.V., USA.

White, D. (2001) cited in Russell, L. (2001) 'E-tendering coming soon to a desktop near you', Construction News IT Report, Report No/ 4927, published on November 8, available at http://www.cnplus.co.uk/IT/ReportDetails/?channelid=10\&report ID=4927. 